\title{
Analysis of influencing factors and suggestion on evaluation index system of green city public transportation enterprise*
}

\author{
Wen-Jing Wang, Yue Qian, Guo-Liang Qiao and Li-Yuan Ding \\ Key Laboratory of Technology on Intelligent Transportation Systems, \\ National Center of ITS Engineering and Technology \\ Research Institute of Highway, MOT, \\ Beijing 100088, China; \\ E-mail:wwj@itsc.cn \\ PH (010)62079526
}

\begin{abstract}
The energy saving and emission reduction of public transportation enterprises is very important. What factors affect these jobs? Through investigating 7 cities of different scale and different places, we can know actual data. By comparing the data of different cities, we can analyze the influence of different factors on energy consumption, such as vehicle level, service level and so on. These studies can provide objective data for the evaluation index system of green city public transportation, and guide the direction of energy saving and emission reduction for public transportation enterprises.
\end{abstract}

Keywords: Energy Saving and Emission Reduction; Public Transport Enterprises; Energy Index.

\section{Introduction}

In China, there have been some researches on the evaluation index system of low-carbon transportation, including low-carbon channel construction and traffic energy consumption statistical monitoring system. In the field of public transportation, the system of urban passenger traffic statistics report forms can monitor the total energy consumption and transportation of urban public transport. However, once a year the statistics cannot monitor the situation of energy consumption. Beijing standard about "Evaluation methodology on fuel consumption forbus/trolley bus"[1] explained statistical classification and statistical index of energy consumption, including the type of energy, the number of vehicles, energy consumption, driving mileage, total operating mileage, passenger volume, passenger turnover quantity and so on.

On the basis of this, the research on the evaluation index system of green urban transportation enterprises has a positive significance for the energy saving

\footnotetext{
* This paper is supported by the Energy Conservation and Emission Reduction Ability Construction Project of Ministry of Transport of People's Republic of China, Grant No. 2015-JNJP-016-062.
} 
and emission reduction and sustainable development of urban transportation enterprises in china.

\section{Influencing Factors}

The influence factor is the foundation of the evaluation system; the evaluation system can reflect the influence factor. Analysis of affecting factors of green development of public transport enterprises, the scope of the study should be clarified first. On the one hand, the urban public transport is an important part of the urban infrastructure; public transport enterprises have the responsibility for social services. On the other hand, as a market economy, the public transportation enterprises need to control the operating cost. Take Wuhan as an example, WuhanBus Company is a state-owned company, andits main task is the public transport, but it still has a plurality of branch, including ferry, materials, advertising, and tourism and so on.

We have investigated 7 different cities; their energy consumption per unit is different, as shown below:

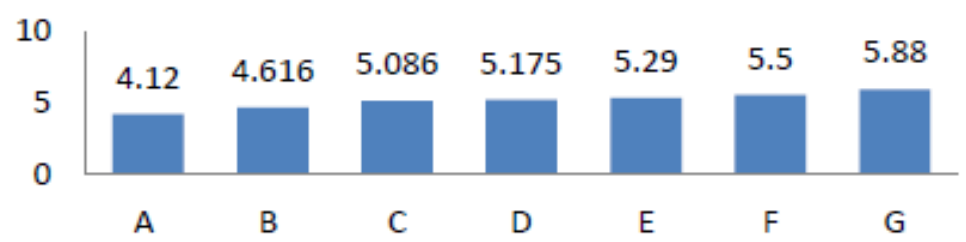

Fig.1. Energy consumption per hundred kilometers of difficult cities.

\subsection{Energy consumption of public transport enterprises}

Energy consumption of public transportation enterprises includes [2] operation and non-operation energy consumption. Operation energy consumption is required by the vehicle to ensure its own operation and its terminal operation. Itincludes the consumption of gasoline, diesel oil, natural gas and electricity consumption. Non-operation energy consumption is energy consumption of enterprise's daily management and station operation. And it is mainly the consumption of electricity. Therefore, the scope of this paper is the operation energy consumption.

\subsection{Bus}

The vehicle level of the public transportation enterprise directly affects the energy consumption level of the enterprise. 
Table 1. Energy Consumption Characteristics of Different Vehicles [3, 4].

\begin{tabular}{|c|c|c|}
\hline classification & Vehicle type & Energy Consumption Characteristics \\
\hline $\begin{array}{c}\text { Traditionalenergy } \\
\text { vehicles }\end{array}$ & Diesel engined car & More emissions \\
\cline { 2 - 3 } $\begin{array}{c}\text { Clean energy } \\
\text { vehicles }\end{array}$ & Gasoline vehicle & Emissions are lower than diesel vehicles \\
\cline { 2 - 2 } & LNG & $\begin{array}{c}\text { Energy consumption is lower than the } \\
\text { traditional energy vehicles, CNG is } \\
\text { superior to LNG in economic and } \\
\text { environmental protection }\end{array}$ \\
\hline \multirow{2}{*}{$\begin{array}{c}\text { Energy saving and } \\
\text { new energy vehicles }\end{array}$} & $\begin{array}{c}\text { Electric vehicle } \\
\text { Plug in hybrid electric } \\
\text { vehicle }\end{array}$ & No tail gas pollution, low noise \\
\cline { 2 - 2 } & $\begin{array}{c}\text { Non plug-inhybrid } \\
\text { electric vehicle }\end{array}$ & $\begin{array}{c}\text { Lower fuel consumption per hundred } \\
\text { kilometers }\end{array}$ \\
\hline
\end{tabular}

Table 2. Energy consumption per hundred kilometers of public transportation enterprise with different fuel types.

\begin{tabular}{|c|c|c|c|c|c|c|c|}
\hline enterprise & A & B & C & D & E & F & G \\
\hline $\begin{array}{c}\text { (kgce/100 km) } \\
\text { Main fuel types } \\
\text { of vehicles }\end{array}$ & $\begin{array}{c}\text { Diesel } \\
\text { engined bus }\end{array}$ & $\begin{array}{c}\text { Diesel } \\
\text { engined bus }\end{array}$ & $\begin{array}{c}\text { Natural } \\
\text { gas }\end{array}$ & LPG & $\begin{array}{c}\text { Natural gas } \\
\text { \& diesel oil }\end{array}$ & $\begin{array}{c}\text { Natural } \\
\text { gas }\end{array}$ & $\begin{array}{c}\text { Natural } \\
\text { gas }\end{array}$ \\
\hline
\end{tabular}

\subsection{Management and system of rewards and penalties}

Energy management, organizational structure and financial support will affect energy consumption and emissions. Driving habits directly affect the energy consumption and the cost of the enterprise. It can be seen from the investigation in Guangzhou and Wuhan, the energy consumption of enterprises accounted for more than $50 \%$ of the tota cost. Bus companies usually develop line fuel consumption standards, when the consumption of the driver under this standard, the company will give them a reward, otherwise there will be penalties.

\subsection{Service level}

Due to the public welfare and service requirements of public transport enterprises, when considering energy saving and emission reduction, we should meet the requirements of operational scheduling and service level first. But different service levels have an impact on the allocation of public transport vehicles and fuel economy. For example, the higher the level of service requirements, the smaller the departure interval, the higher demand for public transport vehicles, and in this case fuel consumption will increase. 
Table 3. Energy consumption per hundred kilometers of different speeds.

\begin{tabular}{|c|c|c|c|c|c|c|c|}
\hline City & A & B & C & D & E & F & G \\
\hline $\begin{array}{c}\text { Energy consumption } \\
\text { per hundred kilometers }\end{array}$ & 41.2 & 46.16 & 50.86 & 51.75 & 52.9 & 55 & 58.8 \\
\hline $\begin{array}{c}\text { bus average speed rush hour } \\
(\mathrm{km} / \mathrm{h})\end{array}$ & 16 & 14 & 12.9 & 17.92 & 15 & 12 & 12.46 \\
\hline
\end{tabular}

\subsection{Operation management}

Reasonable operation plan can increase the full load rate, and it also makes the vehicle travel at the speed of the economy, thus saving energy. Through the optimization of the line network, itcan improve the efficiency of public transport operations, reduce ineffective mileage, improve travel sharing rate, and promote energy-saving emission reduction. As a result of the use of enterprise intelligent system, fuel consumption data can be collected and controlled.

\subsection{Application of energy-saving technology}

When the bus companies to buy vehicles, the plant will be put forward to the requirements of optimize vehicle, so that the situation of the vehicle to match the characteristics of the city and to save energy. In addition, when the air conditioning on the bus turn on, the energy consumption of the vehicle equipment accounts for $10 \%-20 \%$ of the total energy consumption. Therefore, it is necessary to use energy-saving vehicle equipment.

\subsection{Region character}

The line length and repetition coefficient of the city is different because their different spatial layout, such as the direction of a strip of the city's line length will be longer, the distance of the vehicle will be longer.

Different terrain of the city, the level of energy consumption of public transport companies are not the same. Unit energy consumption in mountain cities is higher than that in plain cities. Taking some cities in the survey as an example, the following Figure 2 shows. 


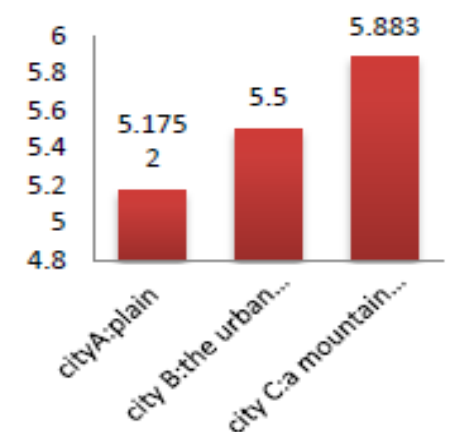

Fig. 2. Energy consumption per ten thousand $\mathrm{km}$.

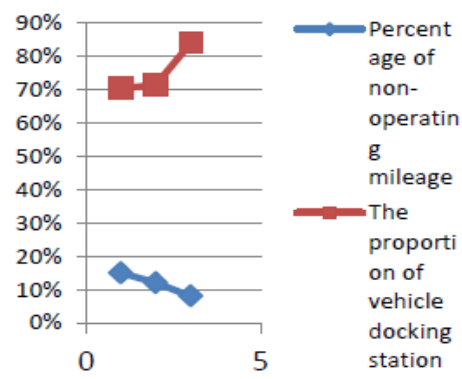

Fig. 3. The percentage of non-operating mileage and vehicle docking station.

The construction site of the gas station and the parking place will affect the non-operating mileage of the bus. It can be found that the bus mileage accounted for more than $13 \%$ of the total mileage in the research. Because of the different geographical position and spatial distribution of the city, energy consumption is also different.

The lower the proportion of vehicle docking station set more far, the higher the proportion of non-operating mileage. As shown in the following Figure 3.

In summary, there are many factors that affect the bus company's energy-saving emission reduction, including bus, management and system of rewards and penalties, service level, operation and management, application of energy-saving technologies, regional characteristics and so on.

\section{Index System Construction}

\subsection{Evaluate targe}

Study and establish a feasible evaluation index system of green city public transportation enterprises, to evaluate the level of energy-saving and emission reduction. With scientific and reasonable evaluation index, to indicate the 
direction of the enterprise, and guide enterprises to implement energy-saving and emission reduction measures more targeted and more efficient.

\subsection{The selecting principle of evaluation index}

The energy conservation and emission reduction of urban public transport is not an isolated development goal; it runs through the enterprise daily operation and service. Its development is closely linked with industry development, technological progress and policy changes. Therefore, in order to comprehensively and objectively evaluate the level of energy conservation and emission reduction, the evaluation index system of urban green public transportation enterprises should follow the following principles.

- $\quad$ Systematisms[5]

The selection of evaluation indicators should consider the characteristics of daily production and energy saving and emission reduction, and ensure that the index system can reflect the level of enterprise's green development comprehensively and objectively.

- Rationality

Index system should be established on the basis of reasonable. Index concept should be clear, evaluation indicators and evaluation objectives must be consistent, the indicators should be coordinated and consistent.

- $\quad$ Simplicity

The selection of indicators should be few and simple, indicators should be representative, and should be able to meet the requirements of multi angle evaluation.

- Operational Characteristics

The selection index should consider whether the index data can be obtained, whether the index range can be determined.

\subsection{Index system}

On the basis of analyze influencing factors; the evaluation index system of scientific and reasonable is set up through consulting expert opinions and the research of typical cities in China. As shown in the following Figure 4: 


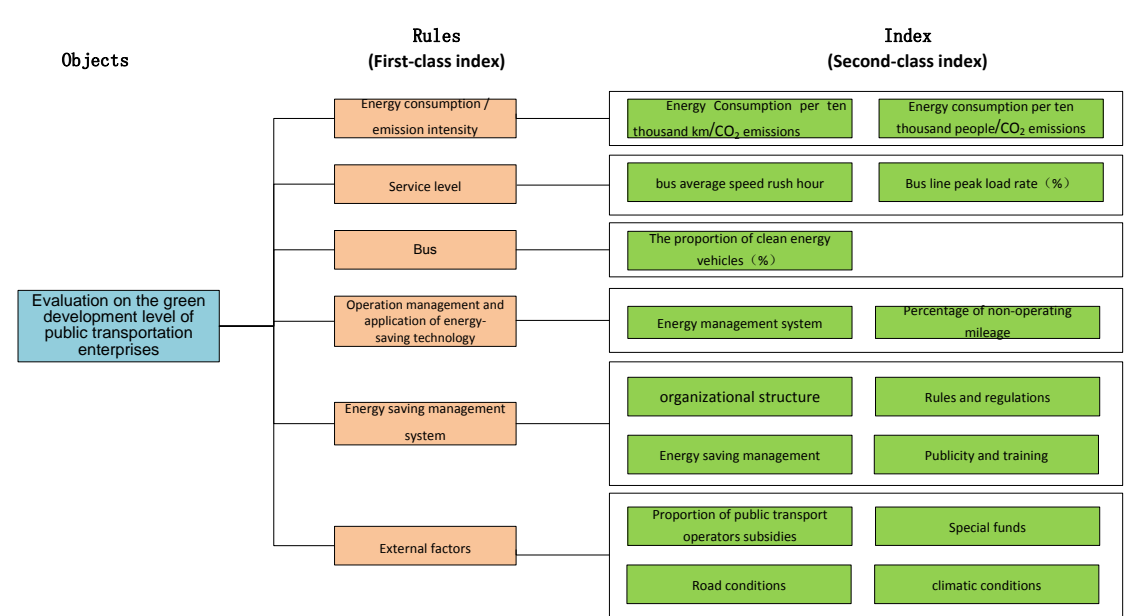

Fig. 4. The evaluation index system of the green development level of public transportation enterprises.

\section{Case Study}

\subsection{Present situation}

Taking into account the level of energy consumption of public transport enterprises is different in different regions; we have investigated the different cities of the plain and mountains.

\section{(1)City A}

City A promotes actively the application of new energy buses. It has 6127 energy-saving and new energy buses in November 2015. City A Transportation Committee and the District Department of transportation signed the "letters of Responsibility for Low-carbon Transportation Development", it is clear that the various tasks of legal person responsibility system and energy-saving emission reduction; and strictly implement the work daily supervision and spot checks from time to time, to promote the standardization of low carbon.

\section{(2)City B}

Wuhan bus group to carry out the work on the new energy bus market research, vehicle research and vehicle test operation. By establishing policy system, improve the low carbon transport development system through the application of energy-saving transport equipment and new technologies, so that the city's public transport energy saving and environmental protection level is significantly improved.

\section{(3)City C}

The proportion of clean energy vehicles in City $\mathrm{C}$ public transportation enterprises is increasing year by year. At present, the bus clean fuel utilization 
rate reached $100 \%$. City $\mathrm{C}$ is in the Yunnan Guizhou Plateau, the relative elevation is 200 meters; the urban traffic congestion is serious.

\subsection{Index data analysis}

Table 5. Index data analysis.

\begin{tabular}{|c|c|c|c|c|c|}
\hline $\begin{array}{c}\text { Serial } \\
\text { number }\end{array}$ & $\begin{array}{c}\text { first-class } \\
\text { index }\end{array}$ & second-class index & City A & City B & City C \\
\hline 1 & \multirow{2}{*}{$\begin{array}{c}\text { Energy } \\
\text { consumptio } \\
\mathrm{n} / \\
\text { emission } \\
\text { intensity }\end{array}$} & $\begin{array}{l}\text { Energy Consumption per ten } \\
\text { thousand km (tons of standard } \\
\text { coal / per ten thousand } \\
\text { kilometers) }\end{array}$ & 5.1752 & 5.5 & 5.883 \\
\hline 2 & & $\begin{array}{l}\text { Energy consumption per ten } \\
\text { thousand people }\end{array}$ & 1.8871 & 1.363 & 1.393 \\
\hline 7 & \multirow{2}{*}{$\begin{array}{l}\text { Service } \\
\text { Level }\end{array}$} & $\begin{array}{l}\text { bus average speed rush hour } \\
(\mathrm{km} / \mathrm{h})\end{array}$ & 17.92 & $12 \mathrm{~km} / \mathrm{h}$ & 12.46 \\
\hline 10 & & Bus line peak load rate $(\%)$ & 96.4 & $120 \%$ & 102.8 \\
\hline 13 & Bus & $\begin{array}{c}\text { The proportion of clean energy } \\
\text { vehicles }(\%)\end{array}$ & 89.89 & $100 \%$ & 100 \\
\hline 16 & \multirow[b]{2}{*}{$\begin{array}{c}\text { operation } \\
\text { manageme } \\
\text { nt and } \\
\text { application } \\
\text { of energy- } \\
\text { saving tech } \\
\text { nology }\end{array}$} & Energy management system & Yes & Yes & Yes \\
\hline 17 & & $\begin{array}{c}\text { Percentage of non-operating } \\
\text { mileage }\end{array}$ & $15 \%$ & $5 \%$ & $12 \%$ \\
\hline 20 & \multirow{4}{*}{$\begin{array}{l}\text { Energy } \\
\text { saving } \\
\text { manageme } \\
\text { nt system }\end{array}$} & organizational structure & Yes & Yes & Yes \\
\hline 21 & & Rules and regulations & Yes & Yes & Yes \\
\hline 22 & & Energy saving management & Yes & Yes & Yes \\
\hline 23 & & Publicity and training & Yes & Yes & Yes \\
\hline 24 & \multirow{4}{*}{$\begin{array}{l}\text { External } \\
\text { factors }\end{array}$} & $\begin{array}{l}\text { Proportion of public transport } \\
\text { operators subsidies }(\%)\end{array}$ & 98.48 & 100 & 19.38 \\
\hline 25 & & Special funds & Yes & Yes & Yes \\
\hline 26 & & Road conditions & plain & plain & $\begin{array}{l}\text { mounta } \\
\text { in }\end{array}$ \\
\hline 27 & & climatic conditions & $\begin{array}{c}20-22 \\
\text { degrees }\end{array}$ & $\begin{array}{c}16 \\
\text { degrees }\end{array}$ & $\begin{array}{c}\text { Summe } \\
\mathrm{r} \text { is not } \\
\text { hot }\end{array}$ \\
\hline
\end{tabular}

Note: data from the research materials of the different urban public transport enterprise.

\subsection{Data analysis}

(1) Due to the application of new energy vehicles and the establishment of enterprise energy management system, the energy consumption of City a public transport vehicles has declined. However, due to the impact of the subway, bus passenger volume decreased. In order to maintain the service level does not fall, the energy consumption per million passengers rise. Therefore, thousands of 
kilometers of energy consumption and energy consumption can reflect the energy efficiency of public transport enterprises to a certain extent.

(2) Due to the road construction of the subway, City C road traffic congestion caused a serious decline in the speed of public transport vehicles, energy consumption levels rise. Therefore, the speed of operation will affect the energy consumption. When considering the energy consumption level of the public transportation enterprise, the running speed index cannot be ignored.

(3) City C and City B public transport vehicles are mostly LNG vehicles. The energy consumption per unit mileage is higher than that of the traditional diesel vehicles and new energy vehicles. Andtheir bus energy consumption per million kilometers higher than in City A.

(4) The City $C$ terrain is mainly mountainous, and its road gradient is larger than that of City A, so the vehicle energy consumption is higher. And City C bus energy consumption per million kilometers higher than in City B, which also illustrates the impact of urban characteristics and vehicle composition on energy consumption.

In summary, the establishment of index system can objectively reflect the green development level of public transit enterprises in different cities.

\section{Conclusions}

In the research and analysis, it is known that the establishment of evaluation index system of the green city public transportation enterprise needs to consider various factors:

(1) In the selection of indicators, as far as possible to select the strength index, rather than the size of the index. For example, with the increase in vehicles, energy consumption and emissions will increase, the total amount of energy consumption and emissions will increase. And with the renewal of the vehicle technology, energy consumption of per hundred kilometers may be reduced.

(2) When establishing the index system, the service level index should be considered. For example: the more suburban lines, the total energy consumption will rise, but due to service requirements, these lines should be established.

(3) The speed of the vehicle has a great influence on the energy consumption of per hundred kilometers. Take City $\mathrm{C}$ as an example, the natural gas consumption of per hundred kilometers is about $70 \mathrm{~m}^{3}$ when congestion, and only about $30 \mathrm{~m}^{3}$ under normal circumstances.

(4)From the established index system, we can see that there are some indexes elements that influence each other. We can analyze the relationship of the indicators using the network analytic hierarchy process, and determine the 
weight of each index.

\section{References}

1. Beijing Municipal Bureau of quality and technical supervision, Evaluation methodology on fuel consumption forbus/trolley bus,(DB11/T 10362013).(In China)

2. Huyoubo, Analysis and Research of Benefits on Energy Saving Environment Protection of Different Models of HEB, (Wuhan University of Technology Master Degree Thesis, December 2015). (In China)

3. Zhangxiliang and Chang shiyan, Contrastive Analysis on the Energy Consumption and the Lifecycle of Main Pollutants of Various New Energy Bus,(New energy vehicles,2008-52).(In China)

4. Shi yue, An Research on Conventional Bus low-carbon Development Strategy and ITS Evaluation System, (SouthwestJiaotong University Master Degree Thesis, May 2015).(In China)

5. Liyang, Chu chunchao and Chen jianying, Construction and application of engry-saving and emission-reduction evaluation index system for road transportation in China, (Journal of Highway and Transportation Research and Development, January 2013).(In China) 